\title{
技術の話題
}

\section{フランスにおけるテレビ電話とディジタル テレビジョンの研究開発現況}

国際電信電話株式会社研究所山本英 雄

フランスにおけるテレビ電話とテレビ会議, および, ディジタルテレビジョンの研究開発の現況 を符号化の問題を中心にして紹介する.

\section{1. まえがき}

筆者はフランス郵電省と $\mathrm{KDD}$ との間の職員交換契約 により, 画像およびデー夕通信分野の交換研修生とし て, 郵電省を中心にして昨年 7 月初めから約 6 力月間フ ランスに滞在した.この間 CNET (Centre Nationals d'Etudes des Télécommunications: 国立電気通信研究 所) と CCETT (Centre Commun d'Etudes de Télévision et Télécommunications: テレビジョンと電気通 信の共同研究所）に打婳像通信分野の研究活動を全 般的に見聞する機会を得，また，英国郵電省の研究所之 西ドイッ郵電省の研究所の画像通信部門を訪問する機会 があった。

本稿ではその際得た情報を基に，日頃紹介される機会 の少ない，フランスにおけるテレビ電話とディジタルテ レビジョンに関する研究現況を報告させていただく、多 少なりと会員諸兄の参考になれば幸いである.

\section{CNET, CCETT の組織と画像通信の研究}

CNET は郵電省に属する研究所で電気通信分野の研 究開発が主任務である．乙の点わが国のNTTの電気 通信研究所に対応する組織であるが，CNET は郵便機 械化や都市防災システムなどの研究も担当している。

電気通信の研究は, 伝送 (Transmission et Espace), 電話交換 (Commutation), 材料物理 (Composantes et Recherches Physiques), テレインフォマチック (Téléinformatique et Reseaux, Speciaux 以下 “TRS”と略 称)の 4 部門に分かれており, 各部門はそれぞれがパリと ブリターニュ (ラニオンとレンヌ) に分散したいくつか の研究部 (groupement) を持っている.また各研究部は

\footnotetext{
"The Present Situation of Videotelephone and Digital Television in France" by Hideo Yamamoto (KDD Research and Development Laboratories, Tokyo)
}

2〜3の研究室 (département) から構成されている

画像通信を担当しているのは TRS である.テレイン フォマチックとは, データ通信, 画像通信, 情報処理の 各技術を総合した新しい通信サービスを意味する概念 で，TRSはこれを目標として，組織上それに対応する 総合的な研究態勢を目ざしているということである。あ っとも，現実にはまだ各分野の研究活動は研究室段階で 独立に進められている。

TRS には, パリのITD (画像とデータ伝送), ラニ オンの CEI (電子計算と情報処理)，それに立場は異な るがレンヌの CCETT という3つの研究部があり, ITD と CCETT が画像通信に関係している.

ITD は, TTI (画像の伝送と処理), NSA（視聴覚新 サービス), TDP (データ伝送と専用網) という研究室 から構成され，前 2 者が画像通信を直接担当している. すなわち, TTI はテレビ電話, テレビ会議, ファクシミ リを，NSA は TICTAC と呼ぶ新しい画像情報サービ スの開発を担当している. TICTAC は家庭のテレビ受 像機を文字とグラフのディスプレイとして利用し, 公衆 電話網を介して情報提供サービスを行うシステムで, 英 郵電省の VIEWDATA と同じ考えのあのである.

CCETT は 1972 年に, 郵電省と TDF（テレビ放送 公社) が共同で設立した独立の研究所であるが，CNET に対しては上に述べたように TRS に属する1研究部の 立場 (多分に概念的に) にある. 研究所の活動の最高方 針之予算は郵電省代表 5 名（CNET 代表を含む）と TDF 代表 5 名から成る運営委員会が決定する.

CCETT の研究領域は ITD に非常に似ており, 画像

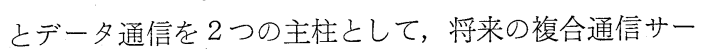
ビスの開発を目標としているが，ITD が 5 年先程度の 短期目標を設定しているのに対し, CCETTは 20 年程 度のより長期目標の仕事を担当するとのととである.

表 1 に示した 6 研究室があり, 画像関係では, ディジ 
表 1 CCETT の研究室の構成

\begin{tabular}{|c|c|}
\hline 研究室名 & 主な課 題 \\
\hline $\begin{array}{l}\text { TSA (視聴覚端 } \\
\text { 末とシステム) }\end{array}$ & $\begin{array}{l}\text { 文字放送応用サービス (ANTIOPE (テレ } \\
\text { デーR DISCR (秘話テレビ), } \\
\text { EPEOS (VTR コントロール)) }\end{array}$ \\
\hline $\begin{array}{l}\text { DTC (ケーブル } \\
\text { テレビ) }\end{array}$ & CATV システム, 㫱星放送受信器 \\
\hline $\begin{array}{l}\text { RSI (情報システ } \\
\text { ムと網) }\end{array}$ & 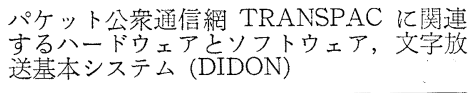 \\
\hline $\begin{array}{l}\text { *CTN (ディジタ } \\
\text { ル伝送と符号化) }\end{array}$ & $\begin{array}{l}\text { テレビディジタル符号化と伝送方式 (OCC } \\
\text { ITAN, 直交変換) }\end{array}$ \\
\hline $\begin{array}{l}* \text { STI(画像処理と } \\
\text { 信号源) }\end{array}$ & 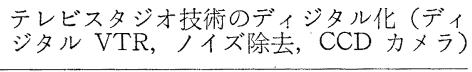 \\
\hline $\begin{array}{l}\mathrm{CAL} \\
\text { ター）（計算セン }\end{array}$ & 計算センターの運用とソフトウェアの開発 \\
\hline
\end{tabular}

*ディジタルテレビジョン担当

タルテレビジョン，CCTV，テレテキスト型の文字放送 システムとその応用システム, グラフィック通信端末な ど，また，デー夕関係では，パケット交換方式による公 衆デー夕通信網 TRANSPAC 関連の研究, 計算機ネッ トワークなどが主な研究課題である.

テレビ放送については，他に研究機関が存在しないの で，CCETT の画像部門はわが国の NHK の研究所に 対応する使命屯持っている.

なお ITDとCCETTに打ける研究スタッフの数は, それぞれ約 300 名抢よび約 200 名（いずれも事務職を除 く）で，そのうち $1 / 3$ がエンジニア（わが国の修士程度 以上に相当) で残りがテクニシャンである．また，人件 費を除いた研究予算は ITD で 4,000万 FF* (1976)， CCETT で1,800万FF (1975) であった．蛇足なが ら，エンジニアの初任月給は約 4,000 FF, 勤続 10 年程 度のベテランになると $8,0000 〜 10,000 \mathrm{FF}$ 位である。

筆者は ITDに3 週間（9月6日〜9月 24 日）, CCETT に 5 週間（9月27日〜10月 29 日）滞在した。 以 下では紙面の制約上，ITD におけるテレビ電話とその 応用であるテレビ会議の現況，および CCETTにおけ るディジタルテレビジョンの研究現況を紹介する.

\section{3. テレビ電話 (VISIOPHONE)}

\section{1 方 式}

フランスのテレビ電話は “VISIOPHONE”と名づけ られている。表 2 にその諸元を示す。この開発は 1970 年に TTI で開始されたが，それまで国内に見るべき技 術はなかったので，実績のあった ATT の PICTUREPHONE の方式を暫定的に採用したという. しかし， その後の独自の研究から CNET はこの方式を積極的に

\footnotetext{
* $1 \mathrm{FF} \doteqdot 65$ 円
}

表 2 VISIOPHONE 諸元

$\begin{array}{lc}\text { フレーム数/秒 } & 30 \\ \text { ライン数/フレーム } & 267 \\ \text { アスペクト比 } & 11: 10 \\ \text { 映像帯域幅 } & 1 \mathrm{MHz} \\ \text { ライン周波数 } & 8 \mathrm{kHz}\end{array}$

肯定している12.

この方式はヨーロッパのテレビ放送方式 (625/25) と の整合が悪いという問題を含んでいる．特に重要なのは フレーム周波数であるが，あえてとの方式を採った理由 は, 元来, フランスの家庭では非常に暗い部屋でテレビ を見ることが多く，毎犁 25 フレームのテレビ放送に何 の問題むないが，明るいオフィスでの使用を前提とする テレビ電話では，それではフリッカが目立ち，毎秒 30 フレームは是非とも必要なことが判明したためというこ とである。

一方，ヨーロッパの他の諸国ではテレビ電話として， フレーム数 25 /秒, 走查線数 300 本前後の方式を想定す るあのが多い. $1 \mathrm{MHz}$ 帯域のテレビ電話器を新たに開 発するより，ライン数変換処理を加えてもテレビ放送用 器機（カメラ，受像器）を利用した方がずっと安くなり そうだというとともあり，テレビ電話とテレビ放送の整 合の良さは方式決定に際して重要な問題である.

CNET は表 2 の方式による大規模な実験網をすでに 運用しており，また近々同じ方式を用いるテレビ会議を 商用化する段階にあるが，ヨーロッパ標準方式 (313/25 が有力と思われる) が採用されることになれば，究極的 にはそれに移行する可能性も残している.このために 25 フレーム/秒であフリッカが目立たない残光時間の長 いCRT の開発もほぼ完成している。

現方式は単色であるが，カラー化の研究も進んでお り，遠からず伝送実験を開始する予定である. カメラと 受像器は放送用のものにライン数変換を付加したものを 利用しており, 走査方式は $313 / 25$, 当面の色信号伝送 方式は $\mathrm{TDM}^{21}$ にっている.

\section{2 符号化方式}

長距離リンクのディジタル伝送のために表 3 に示した 5 種類の符号化方式を開発しており，乙の研究は一段落 したところである，各方式の画質は主観評価の結果から

表 3 VISIOPHONE の符号化方式

$\mathrm{C} 1: 6 \mathrm{Mb} / \mathrm{s} \mathrm{DPCM}(2 \mathrm{MHz}$ 標本化, $3 \mathrm{bits}$ /画素)

$\mathrm{C} 2: 8 \mathrm{Mb} / \mathrm{s}$ サブサンプリング符号化

C 3: $2 \mathrm{Mb} / \mathrm{s}$ 無条件画素補充型フレーム間符号化

C 4: $8 \mathrm{Mb} / \mathrm{s}$ DPCM (2 MHz 標本化, $4 \mathrm{bits}$ /画素)

$\mathrm{C} 5: 2 \mathrm{Mb} / \mathrm{s}$ 条件付画素補充型フレーム間符号化 


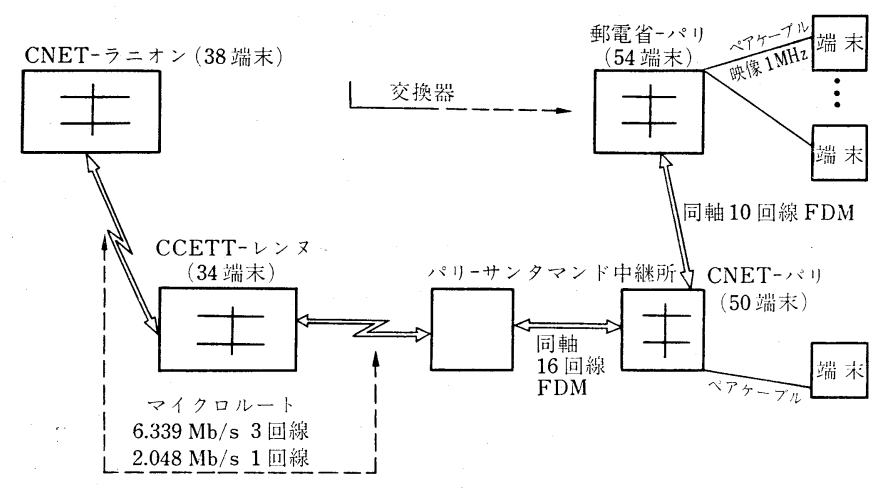

図 1 VISIOPHONE 実験網 ${ }^{3}$

表 3 の上から下へと順に良くなり，C 4 とC 5 は同等と

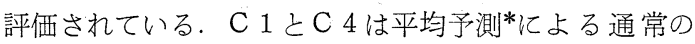
DPCM である. C 2 は映像信号を $800 \mathrm{kHz}$ 亿帯域制限 した後、サブナイキスト周波数 $1.4 \mathrm{MHz}$ で標本化した あのを, $6 \mathrm{bits} /$ 画素で直線埋子化する方式である. 受信 㑡では簡単な内插フィルタで間引かれた画素を補充す る.

C 3 は C 1 を基礎とし， 3 フィールドごとに 1 フィー

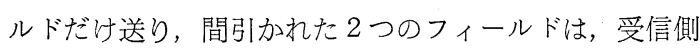
亿拉いて, 前後の送られたフィールドから内挿合成する 方式である.C 5 は BELL 研の FRODEC と同様の考 えによるフレーム間符号化方式であるが制御がより簡単 になっている.

上記 5 者の中で，テレビ電話実験網では現在 C 1 と C 3 が実用されており, 近々商用化になるテレビ会議方式 ではC 5 が使用される予定である。一方，フランスには 現在 $8 \mathrm{Mb} / \mathrm{s}$ 伝送路が存在せぬととと, C 4 とC 5 の画 質がほぼ同等と評価されているととから, 将来とも $8 \mathrm{Mb} / \mathrm{s}$ 方式は実用されそうにない.

なお，具体的な研究計画はないが，研究りーダーはテ レビ電話の実用化に備えて， $1 \mathrm{Mb} / \mathrm{s}$ 以下の符号化方式 の開発澺欲を持っている.

\section{3 テレビ電話器}

PICTUREPHONE 型の端末の他に，ハーフミラーを 使って, カメラとモニターの中心軸が同軸上に並ぶよう にしたテレビ電話端末が開発されており,てちらの方が, 利用者に，より好評だというととである.

\section{4 実験網}

現在運用されている VISIOPHONE の実験網を図 1 に示す。郵電省内に 54 , パリの CNET に50, ラニオ ンの CNET に 38 の端末が設置されており, 日常業務 に実用されている. 図中 CCETT 内の 34 端末は政治的

* 予测関数 $: P(z)=\frac{1}{2}\left(z^{-1}+z^{-H+1}\right), H$ Hラインディレイ
理由とかで現実にはまったく利用されてな い.

交換器と端末の間はペアケーブルによるべ ースバンド伝送, パリ市内の近距離トランク そは同軸ケーブルによるFDM アナログ伝 送を採用している，パリとブリターニュ間は マイクロルートをディジタル伝送路として使 い, $6 \mathrm{Mb} / \mathrm{s}$ のもの 3 回線, $2 \mathrm{Mb} / \mathrm{s}$ のの 1 回線を設定している. 符化方式として前者 にC 1 , 後者にC 3 を適用して打り, $2 \mathrm{Mb} / \mathrm{s}$ 回線は主にテレビ会議の実験に利用してい る.

この実験網は, テレビ電話利用状況の心理的・人間工 学的調查を行うととを目的としており，トラヒックに関 するさまざまの情報が自動的に記録されている3 最初の分析結果—1974 年末〜1975 年末に対して— が報告されている4)。乙れによると VISIOPHONE の 利用は好評で時ととあに日常化されているようである.

\section{5 テレビ会議 (VISIOCONFERENCE)}

現在各国が提案しているテレビ会議方式には, テレビ 放送方式によるあのと，テレビ電話によるあのがある が,フランスは後者を採り “VISIOCONFERENCE”と 名づけている55.

会議場の構成を図 2 亿示す. “各人の前に VISIOPHO$\mathrm{NE}$ モニターとマイク, 会議場の前面に全景用のカメラ と大型モニターが配置され，乙の他通常の電話器, TLX および文書送受に高速 FAX 1 台 $(64 \mathrm{~Kb} / \mathrm{s})$ が用意され ている.

離れた会議場間は $2 \mathrm{Mb} / \mathrm{s}$ の双方向伝送路（上り, 下 り各 1$)$ で結ばれ，音声 $(64 \mathrm{~Kb} / \mathrm{s})$ と FAX 用データ チャンネルはその中に統合されている. 映像の符号化方 式として現在 C 3 を使用しており, 商用時はC 5 亿変え る予定である.

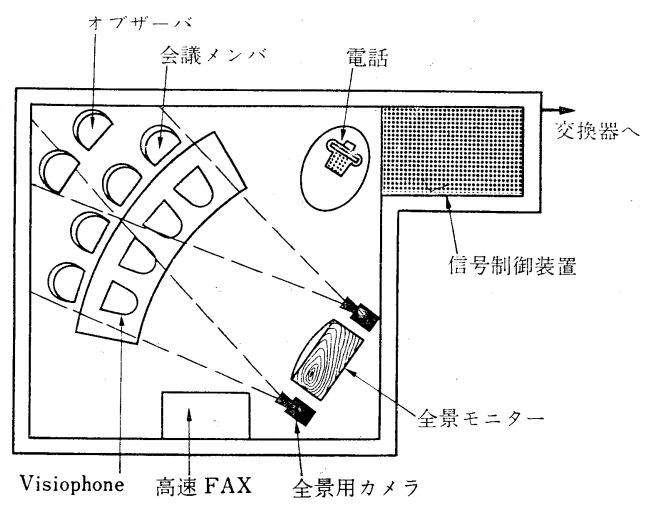

図 2 VISIOCONFERENCE 会場 ${ }^{53}$ 
信号制御装置は，マイクの音声レベルから話者を検出 し，モニターに出す映像を切り変える. 異なる会議場に いる者の間で対話が続いているときは，話者以外の VISIOPHONE には話者の顔が，話者のそれには直前 の話者の顔が表示される，また，同じ会議場内で話しが 続いているときや，同一人が長時間話し 続けるときに は，双方向伝送路の一方の空を利用して，話者のいる会 議場の全景モニターに他方の会場の全景を表示する。む ち万ん各人の VISIOPHONE は前の場合と同様に㗢く.

このテレビ会議は, シンフォニー衛星を介してジュネ ーブの TELECOM 75 会場とパリの CNET の間で (1975 年 10 月), また, パリのユネスコとケニヤのナイ ロビのユネスコ会議場との間で（1976 年 10 月）国際的 にデモンストレーションされている，参加者の多くはこ の会議に満足したという.

郵電省は本年末頃にはパリ，レンヌ，ナントの 3 カ所 に会議場を設けて，VISIOCONFERENCE の商用サー ビスを開始しようとしている.

\section{4. ディジタルテレビジョン}

テレビ放送を対象とするディジタルテレビジョンの研 究は, CCETT の発足以来 NIM (画像のディジタル化) 研究室で行われてきたが, NIM は筆者の滞在中 1976 年 10 月に CTN (符号化とディジタル伝送) と STI (画像 の処理と信号源）との 2 研究室に分離した. CTN は文 字通りディジタル伝送方式とそのための符号化を担当 し, STI はディジタル VTR, ノイズ除去, 方式変換, CCD カメラなどスタジオの信号処理のディジタル化を 担当する. STI の仕事には現在特に目新しいものはな く具体的成果はこれからという状態のように思われた。 ここでは CTN の活動をとり上げる.

\section{1 符号化の目標亡ヨーロッパの標準化の動向}

国際的な番組交換の発展に備えて, また, 各種のディ ジタル信号処理装置のテレビ技術への導入を控えて，ヨ ーロッパ諸国では $\mathrm{EBU}$ を中心に，ディジタルテレビジ ヨンの標準化の機運が高まっている．標準化を実質的に リードしているのはフランスと西ドィッのようで, それ ぞれがSECAM と PALのオピニオンリーダーである. 技術的には英国も, 郵電省研究所*や $\mathrm{BBC}$ を中心重要 な仕事をしているが，ヨーロッパテレビ網の中で英国は

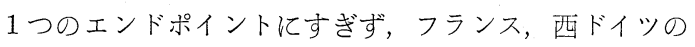
合意がとれれば英国の立場は標準化にはさほど重要でな いというのが, フランスの研究担当者の考えである.

CTN の最近の最大の目標は，フランスの技術的代表 として，ての標準化をリードするととにあるようだ.

\footnotetext{
* Post Office Research Centre
}

この標準化には，（i ）標本化周波数，（ii）伝送ビッ トレイト，（iii）符号化方式の 3 要素があり，それぞれ が互いにからみあっている，てれに対する CTN の目標 は，CCIR 5 段階評点 $4 \sim 4.5$ の画質を達成する，34 $\mathrm{Mb} / \mathrm{s}$ 分離符号化方式 ${ }^{2}$ である. 輝度信号 (以下 “ $Y$ ”) に対する標本化周波数としては $f_{s c} \fallingdotseq 8.8 \mathrm{MHz}, f_{s c}$ : 色搬送周波数）を許容できるとしている．以下これに関 連する事情を紹介する。

\section{（1）伝送ビットレイト}

テレビ国際接続の標準化に最も熱心なのは西ドイッと いう。乙れには，東西両ドイッが，それぞれ SECAM とPAL の異方式を採用しており, 将来の両国間の番組 交換の重要性から，両方式に両立するディジタル標準を 定めたいという事情がある，ところで，ドイッは中規模 都市が散在する国で, ディジタル伝送路幹線としては, 第 3 次群の $34 \mathrm{Mb} / \mathrm{s}$ が必要充分で，乙れ以上高速の伝 送路を建設する予定は当分なく，西ドイツ郵電省関係者 は，テレビ国際接続にむそれ以外は認めない方針とい う.

一方，フランスの事情も微妙で，公衆通信網を提供す る郵電省は，ディジタル幹線として， $2 \mathrm{Mb} / \mathrm{s} ， 8 \mathrm{Mb} / \mathrm{s}$, $140 \mathrm{Mb} / \mathrm{s}$ を建設する考えであり，当分 $34 \mathrm{Mb} / \mathrm{s}$ を建設 する計画はない，乙れは，フランスには，パリ，リ才 ン，マルセイユ等の少数の大都市を除くと，他は小都市 ばかりで，大都市間には $140 \mathrm{Mb} / \mathrm{s}$ が必要である一方， 他の場合には $8 \mathrm{Mb} / \mathrm{s}$ で充分で, $34 \mathrm{Mb} / \mathrm{s}$ の適用領域が ないととによる。しかし，フランスは西ドイツと異な り，テレビ伝送路は TDF が独自に保有しており，将 来, TDF がテレビ専用の $34 \mathrm{Mb} / \mathrm{s}$ 伝送路を建設する可 能性が残されている，郵電省はこれに反対しない意向之 いう.

これに対し，英国は国内の $70 \mathrm{Mb} / \mathrm{s}$ 伝送路をテレビ中 継に適用すると考えられているが，フランスとドイッの 合意が成れば，少なくともヨーロッパとのインタフェー スを $34 \mathrm{Mb} / \mathrm{s}$ に合せるととに同意すると期待されてい る.

(2) 符号化方式

フランスはか称が称分離符号化を主張している，直接

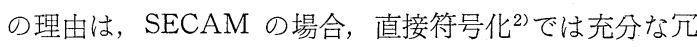
長度除去が期待できないためである。しかし，それだけ でなく，フランスは現在，ディジタルテレビジョン時代 には，方式変換の必要のない世界的に統一された標準方 式を採用すべきだという理想的立場をとっている，具体 的には， $Y, R-Y, B-Y レ$ ル゙での分離符号化を提 唱し，また国内ではディジタル SECAM を使用しない ことをすでに決定している. 
他方，PAL 諸国は一般に直接符号化を支持している. 西ドイッでは，スタジオ内では $4 f_{s c}$ 標本化による直接 PCM，すなわちディジタル PAL を採用する意向とい う.ただし, 先述の伝送路事情と東ドイッの SECAM との接続の必要性加ら, 国際接続に $34 \mathrm{Mb} / \mathrm{s}$ 分離符号化 を採用するととに異論はないようである。

符号化品質として, 先述のように, フランスは CCIR 評 点 4〜4.5を目標としている. 現用 SECAM の画質は 3.8 と評価しているので7), ディジタル化によりそれ以上 の水準を求めていることになる．乙の目標を達成した方 式として, 後述の OCCITAN による研究結果に基づき, 分離 $\mathrm{DPCM}$ による $52 \mathrm{Mb} / \mathrm{s}$ 符号化方式を最近完成し, 伝送実験を行っている.しかし， $34 \mathrm{Mb} / \mathrm{s}$ のレイトで は，その品質をまだ実現できないとし，4.2〜4.5 節に 述べるような研究を続けている.

なお，西ドイツはアダプティブ量子化を採用した 34 $\mathrm{Mb} / \mathrm{s}$ 分離 DPCM により, 現用 PAL のスタジオでの 品質にほぼ等価なむのが実現できたとしている.

(3) 標本化周波数

さまざまのディジタル信号処理がテレビスタジオに導 入され始めた現在, 標本化周波数の標準化は最も早急に 望まれるあのである. ヨーロッパでは本年内にも合意が 成立しそうな気配であった. PAL 諸国の一般的な意見 は, スタジオのディジタル PAL と国際接続用の $34 \mathrm{Mb} / \mathrm{s}$ 分離符号化との間の, 色分離・合成処理をディジタル的 に行い易いように $2 f_{s c}$ を適当としている. フランスは 完全な分離符号化を考えているから, 標本化周波数之 $f_{s c}$ を関係づける必要はまったくない.しかし，サブナ イキスト標本化 ${ }^{10)}$ の必要性から，ライン周波数の $1 / 2$ の 奇数倍を必要とし，またエッジビジネスの評価から，ス チールサンプルパターン（フレームごとにサンプル位置 を一定させる方法，サブナイキスト標本化と両立させる ためには，フレームどとに最初のサンプル点の位相を初 期設定しな括す必要がある）が望ましいとしている. 周 波数として $2 f_{s c}(\fallingdotseq 8.8 \mathrm{MHz})$ 近傍は受入れられるとし ているが，完全な $2 f_{s c}$ では上の条件を満たせず，乙の 調整妥協がいまの問題である.

\subsection{OCCITAN}

CCETT は SECAM分離 DPCM 方式を検討するため 1 年程前に OCCITAN ${ }^{6)}$ と称する実験システムを完成さ せた，乙れは符号化方式の諸パラメーターをミニコンの 制御で即時に変更できるようにし，各パラメーター值に 対する画質の主観評価を能率良く体系的に遂行できるよ うにした DPCM 装置(ハードウェア)である. 符号化の 特色は，Y信号と色差信号 (以下，“C”)を，それぞれに 応じたパラメーターで独立に DPCM すること,および，

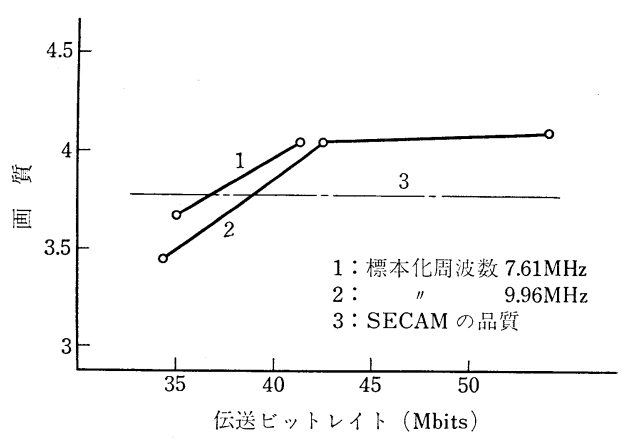

図 3 分離 DPCM の画質/伝送ビットレイト7)

2つの色差信号は線順次で送るが, 受信側では, 間引か れた色差信号を送られた上・下のラインから内挿合成す ることにある。

符号化パラメーターとしては，標本化周波数 (10.75〜 $7.61 \mathrm{MHz}$ の間 6 種 $(Y), 2.84 \sim 1.79 \mathrm{MHz}$ の間 6 種 (C), サブナイキスト標本化に付随する補間フィルター 4 種, 予測関数 (前值, 平均 2 種, 平面), 量子化特性 (3 〜 bits）が選択できる. また，各標本化周波数につい て，いくつかのサンプルパターン一一直交格子状かスチ ールサンプルパターンかなど——も選択できる.

これによる詳しい検討結果は文献 ${ }^{7)}$ 報告されてい る.図 3 はその中の最も総合的な結果で, 伝送ビットレー トと画質との関係を，Yに対する2種の標本化周波数を パラメーターとして表わしたあので方る。C信号は 2.63 $\mathrm{MHz}, 4$ bits/画素で標本化されている. 予測関数として は，Yに平均予測，C飞前值予測，サンプルパターン之 しては,スチールサンプルパターンを用いている．また， 伝送レイトは，ブランキング期間を実データ伝送に利用 すること，执よび誤り訂正コードのため 10\%のて長情 報を付加することを前提として求めたものである。

この結果は，CCIR 評点 4 以上の画質に対して，40 $\mathrm{Mb} / \mathrm{s}$ 程度の伝送レイトが必要なととを示している。

\section{3 直交変換符号化}

Hadamard と Haar を用いた直交変換符号化を研究 している，乙の場合も分離方式で， $Y$ と 変換符号化する方法である. $4 \times 4$ 次, $8 \times 8$ 次, $16 \times$ 16 の 2 次元直交変換を対象として, シミュレーション8

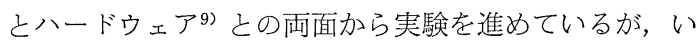
まは $Y$ だけが対象で，カラー画面を扱うには至っていな ().

これまでの研究結果から，直交変換符号化で従来一般 的に採られるゾーンフィルタリング法では， $34 \mathrm{Mb} / \mathrm{s}$ 伝 送の目標を実現できず，適応型符号化が必要としてい る. 
通常のゾーンフィルタリングでは, 送るべき sequency 成分之それに対するビット配分が，とりあつかう画像の マクロな統計的性質によって画一的に決められる。乙の ため, 個々の画像については, その内容により, 送られ ない高次 sequency 成分の中に視覚的に無視できないエ ネルギーを持つものが生じ，乙れによる画質劣化がしば しば観察される。このような成分の発生率は統計的には 非常に小さいから，アドレスを付して画面でとに選択的 に送ってやるのが有効である.

研究担当者は，このような適応型フィルタリングによ って，同等の画質を得るのに従来の方法にくらべて 1 画 素当り 1 bit 程度の節約が可能としている. 現在, 標本 化周波数 $12.5 \mathrm{MHz}$ の屯とで, $16 \times 16$ 次の 2 次元 Hadamard 变換で, CCIR 評点 4 4. 5 を $3 \sim 3.5$ bits/画素 で実現しているが，目標の $34 \mathrm{Mb} / \mathrm{s}$ 伝送にはまだ距離 がある.

なお, 同様の適応型直交变換は, CCETT と協力関係 にある Philips のパリ研究所でむ研究されている.

\section{4 心理・視覚的アプローチ}

DPCM にしろ直交変換にしろ, 従来の簡単なやり方 だけでは, $34 \mathrm{Mb} / \mathrm{s}$ で CCIR 4 4.5 の品質を達成する には不充分である。CCETT の研究者は，乙れを打開す る最む現実的な方法は，視覚心理的特性をできるかぎり 有効に利用するととにあると考えており, このため各種 の符号化ひずみ (グラニュラーノイズ，エッジビジネ ス，等々）の検知限を客観量化し，それを符号化方式の パラメーターの中に積極的に組み込んで行く之いう力向 を摸索している、筆者の滞在中は，エッジビジネスの検 知限の測定をさかんに行っていた，具体的成果屯遠から ず期待できそうである.

\section{5 カラー非直線 PCM}

カラー信号の PCM に際し, 色覚の非直線特性を利用 して，視覚的に等間隔になるような量子化を行うという 研究む最近開始された。いまは理論モデルによるシミュ レーションの段階で，実験には至ってないが，悲観的に 見てむ， 5 bits/画素で直線量子化 PCM の 8 bits/画素 飞相当する効果が期待される之いう.

\section{5.むす び}

フランスに打ける, テレビ電話の現況, また, ディジ タルテレビジョンの現況をヨーロッパにおける符号化方 式の標準化という点に焦点を扔いて紹介した．乙れらの

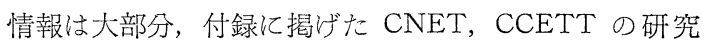
者とのインタビューや議論を通じて得たものである. 対 応する文献のある物はできるだけ文中に示した，㐨わり に，フランス研修の機会を与えられた $\mathrm{KDD}$, フランス
郵電省, CNET, CCETT 関係各位に感謝します。

(昭和 52 年 5 月 9 日受付)

\section{〔参考文 献〕}

1) M. Blanc: Le visiophone pourquoi pas?, L'onde electrique, 55, 2 (1975)

2) 大平: “高能率符号化方式” 4 章，テレビ誌，30，10 (1976)

3) A. Poirier, et al. : Equipment d'observation de trafic des autocommutateurs de visiophones, Commutation et electronique, 50 (1975.7)

4) L. Fleury, et al.: L'utilisation de la visiophonie, Rapport/ITD/TTI/30 (1976. 7)

5) M. Blanc, et a1. : La visioconférence, L'onde electrique, 55, 7 (1975)

6) J. Poncin, et al. : Système de codage numérique de l'image de télévision: le projet OCCITAN, L'echo des recherches (1976. 1)

7) J. Sabatier: Le codage différentiel des composantes du signal de télévision couleur, Acta electronica, 19, 3 (1977)

8) H. Tchen, et al. : Codage par transformation orthogonales de Hadamard et Haar des signaux television, Rapport CCETT, NIM/T/3/76 (1976. 3)

9) H. Bacchi: Réalisation d'un transformateur d'images en temps réel, Annals de Télécommunications, 30 , 9-10 (1975)

10）藤尾ほか：“画像符号化の基琁”の 4.1，テレビ誌，30, 11-21 (1976.10)

付録 CNET, CCETT におけるテレビ電話 ディジタルテレビの研究リーダー

\begin{tabular}{|c|c|c|}
\hline 名 前 & ポジション & 主な担 務 \\
\hline \multicolumn{3}{|c|}{ CNETーITD：テレビ電話とテレビ会議関係 } \\
\hline $\begin{array}{l}\text { BLANC } \\
\text { SEGUIN } \\
\text { LECLERCQ } \\
\text { MICIC } \\
\text { PETIT } \\
\text { CAILLEAUX } \\
\text { TEMINE } \\
\text { PAQUETTE } \\
\text { POIRIER } \\
\text { ROBIN } \\
\text { GIRARD } \\
\text { FLEURY }\end{array}$ & \begin{tabular}{|c|} 
ITD 部長 \\
同上 部長付 \\
TTI 室長 \\
同上 補佐 \\
TTI エンジニア \\
" \\
" \\
" \\
" \\
" \\
"
\end{tabular} & $\begin{array}{l}\text { 符号化 (ハードウェア) } \\
\quad " \text { (シミニレーション) } \\
\quad " \text { (理諭) } \\
\text { 伝送路 } \\
\text { 交換器, テレビ会議 } \\
\text { CCDセンサー,CRT, 材料部品 } \\
\text { 端 末 } \\
\text { アセスメント }\end{array}$ \\
\hline \multicolumn{3}{|c|}{ CCETT: ディジタルテレビ関係 } \\
\hline $\begin{array}{l}\text { ONRUYT } \\
\text { ONCIN } \\
\text { ABATIER }\end{array}$ & $\begin{array}{l}\text { CCETT 所長 } \\
\text { 所長付参事官 } \\
\text { CTN 室長 }\end{array}$ & $\begin{array}{l}\text { ディジタルテレビ全般のリ } \\
\text { 名ー符号化 (DPCM, OCCITA }\end{array}$ \\
\hline KRETZ & CTN エンジニア & 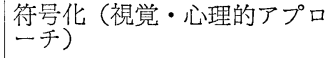 \\
\hline $\begin{array}{l}\text { MOTCH } \\
\text { RANQUET } \\
\text { NASSE } \\
\text { LOUINEAU } \\
\text { TCHEN }\end{array}$ & $\begin{array}{c}\quad " \\
\quad " \\
\text { STI 室長 } \\
\text { STI エシジ } \\
\text { TSA エンジニア }\end{array}$ & $\begin{array}{l}\quad \text { "（直交変換） } \\
\text { ディジタル伝送システム } \\
\text { スタジオ信号処理 } \\
\text { CCD カメラ } \\
\text { 符号化（直交変換） }\end{array}$ \\
\hline
\end{tabular}

